\title{
Retraction Note: Criminal tendency detection from facial images and the gender bias effect
}

Mahdi Hashemi ${ }^{1 *}$ (D) and Margeret Hall ${ }^{2}$

The original article can be found online at https://doi. org/10.1186/s40537-0190282-4.

${ }^{*}$ Correspondence: mhashem2@gmu.edu ${ }^{1}$ Department of Information Sciences and Technology, George Mason University, 4400 University Dr, Fairfax, VA 22030, USA

Full list of author information is available at the end of the article

\section{Retraction to: J Big Data (2020) 7:2 https://doi.org/10.1186/s40537-019-0282-4}

The authors have retracted this article [1] because they did not seek approval from their ethics committee before undertaking this study that uses human biometric data. Both authors agree with this retraction.

\section{Author details}

${ }^{1}$ Department of Information Sciences and Technology, George Mason University, 4400 University Dr, Fairfax, VA 22030, USA. ${ }^{2}$ College of Information Science and Technology, University of Nebraska at Omaha, 1110 S 67th St, Omaha, NE 68182, USA.

Published online: 30 June 2020

\section{Reference}

1. Hashemi M, Hall M. Criminal tendency detection from facial images and the gender bias effect. J Big Data. 2020;7:2. https://doi.org/10.1186/s40537-019-0282-4.

\section{Publisher's Note}

Springer Nature remains neutral with regard to jurisdictional claims in published maps and institutional affiliations. the source, provide a link to the Creative Commons licence, and indicate if changes were made. The images or other third party material in this article are included in the article's Creative Commons licence, unless indicated otherwise in a credit line to the material. If material is not included in the article's Creative Commons licence and your intended use is not permitted by statutory regulation or exceeds the permitted use, you will need to obtain permission directly from the copyright holder. To view a copy of this licence, visit http://creativeco mmons.org/licenses/by/4.0/. 